\title{
Digging in the penumbra of master categories
}

\author{
Saskia Sassen
}

Burawoy's 'For Public Sociology' traces the many diverse ways in which our discipline can encompass public sociologies. This is a thoughtful piece, and an exciting one. It explodes the category of public, showing us its many facets. There is little I disagree with in Burawoy's eleven theses. I found particularly important the notion of provincializing American sociology - which also resonates with the effort today among several historians to provincialize Europe. And I found Burawoy's insistence that there are many diverse publics critical to the task he calls for. It is a brilliant, intelligent, generous, map of the project that he names For Public Sociology. It is in the spirit of the collective work Burawoy calls for that I make the following comments.

I want to go digging. I want to detect the lumpiness of what seems an almost seamless map - though perhaps it appears to me as seamless precisely because I agree fully with Burawoy. Are there fractures in this project, is there a fallacy or a flaw we are missing? This digging is part of the work that needs to be done.

Perhaps a first digging site is the built-in pluralism of Burawoy's map. I think Burawoy is right when he argues that it is necessary to recognize and accommodate the fact of many different norms and aspirations, and that while we may disagree with many of these, we cannot and do not want to suppress them, no matter how distasteful some might seem. I agree, yes, but I want to argue that if we are to strengthen and develop public sociology we need to go beyond the notion that the first step is accepting the fact of a multiplicity of different publics and different public sociologies. Rather, we need some reflexivity à la Giddens. We need to produce and recognize the normative grounds from which critical discourses and theorized critiques can get started, can engage power, and we can engage each other by going beyond a mere acceptance of differences no matter how public the publics that represent or contain them. While Burawoy's theses do not necessarily preclude this, there is a sense that many of the theses move in the direction of a type of 
pluralism. Perhaps this is merely a function of wanting to write a brief, and open, text.

Is what I raise a significant issue, or an issue at all, in the project of public sociology as introduced by Burawoy? I agree that we must accept the copresence of different norms and logics organizing different types of sociology and types of publics. But we must interrogate the project itself, not to destroy it, but to give it traction both as a form of knowledge and of engagement. Nor is it a matter of chosing one's favourite type of public sociology, even though we of course will chose the ones we think are best. One critical question then is whether the almost inevitable pluralism present in Burawoy's generous accommodating of very diverse ways of engaging public questions glides over some serious frictions with which would be better to engage? Fighting it out might be productive. Is pluralism here just a stance of openness? Or is it also functioning as a master category?

From where I (Sassen 2006) look at it all, master categories have the power to illuminate, but theirs is blinding power thereby also keeping us from seeing other presences in the landscape. They produce, then, a vast penumbra around that centre of light. It is in that penumbra that we need to go digging. A first point I want to make is that pluralism should be problematized rather than assumed to be good because it (supposedly) allows for all voices to speak. When we begin to think of it as a master category, we can posit that it is one way of structuring a discursive space, with its own power logics and exclusions.

Taking this further, a second digging site is about master categories themselves. Should the question of master categories be part of the work of developing a public sociology and should this work be done in and with diverse publics? In this formulation of the question I am clearly addressing a certain kind of public, perhaps one not so very public. But the argument I am making is that the work of detecting the presence of master categories that simultaneously illuminate and obscure should at least partly be done in the engagement with diverse publics.

It may sound like a project that belongs deep inside the academy, but I am arguing it does not. Public sociology, not only critical theoretical sociology, is itself a critical venue for doing this work. That is to say, a public sociology also needs its publics for this kind of theoretical work - rather than confining the work of theorizing to critical theory as a specialized discipline. Why do we have to adapt/adjust our public sociology speech acts to whatever our representation of the specific public we may be addressing or engaging with. We know that people who are not trained academically can theorize in the sense of the old Greek notion of teoria as seeing. Why does a public sociology have to avoid making theory as part of its publicness? This is not to deny that 'critical theory' or other types of theory can make enormously valuable contributions that are also necessary for a public sociology. 
We need to explore the conviction among academics that theory discolours the public moment of sociology (even though it can provide the insights and unsettle traditional understandings). To participate in this moment, so the notion runs, theory first needs to change clothes, which is to say, be de-theorized, because if we expect to communicate with our 'public' publics, we need to leave theory behind in the academy. I want to contest this and argue that we can engage our publics in the work of theorizing as seeing (without using arcane languages) and can learn a lot, and hopefully so can they.

We should not make a master category out of theory. Let's bring it down, and consider that part of having a vigorous public sociology is that we can work at theorizing with our publics, accepting that they also can theorize - can see, and may indeed see what we cannot see, because we are blinded by the enormous clarity of our theories. I am raising this as a question, not insisting it ought to be so, nor seeking to persuade anyone.

(Date accepted: June 2005)

\section{Bibliography}

Sassen, Saskia 2006 Territory, Authority and Rights: From Medieval to Global Assemblages, Princeton University Press. 